\title{
EDESSA IN THE ERA OF PATRIARCH MICHAEL THE SYRIAN
}

\author{
JOSEPH TARZI
}

BURBANK, CALIFORNIA

\section{INTRODUCTION}

[1] The year 1999 not only marked the $800^{\text {th }}$ anniversary of the departure of Patriarch Michael the Great, but also the $75^{\text {th }}$ anniversary of the forced mass-exodus of the Syriac Orthodox people of Edessa, and the migration of the Syriac Church of Edessa to Aleppo, Syria.

[2] To commemorate the two occasions, I chose the topic of my paper to be "Edessa at the time of Patriarch Michael the Great." Although Patriarch Michael was born in 1126, and died in 1199, the period covered in this presentation is almost entirely the $12^{\text {th }}$ century that is from the year 1100 to $1200 \mathrm{AD}$.

\section{A QUICK GLANCE AT EDESSA IN THE PERIOD BETWEEN THE $7^{\mathrm{TH}}$ AND $12^{\mathrm{TH}}$ CENTURIES}

[3] As of the seventh century and until the beginning of the thirteenth century, Edessa was ruled predominantly by men of alien stock, professing a faith alien to that of most of its inhabitants. The Edessans were, however, already accustomed to being ruled by strangers. Since the end of the Abgar dynasty, the city had been administered by governors nominated by Constantinople, who were rarely native to Osrhoene. Most of these governors were of different religions. As of the end of the fifth century, the largest 
community in the city was Syriac Orthodox, ${ }^{1}$ whereas most of the governors were Melkite. Between the two sects the animosity had become so bitter, and persecution so violent that the Edessans had welcomed the Moslems to their city as deliverers.

Edessa fell to the Moslem Arabs in 639 AD. It surrendered to the Arab general Iyad Ibn Ghanm² who granted to the Bishop of Edessa the terms of the surrender. According to these terms, lives and property of the Christian inhabitants were to be secured as "abl-al-dhimma," in return for one dinar and two measures of flour to be paid for each male citizen. The first Moslem governor of Edessa is said to have been a certain Abu Badr.

At the beginning of the second half of the eighth century, the Abbasids captured Edessa. By order of the Caliph, the walls of Edessa were demolished completely. Edessa was involved in the struggle between al Amin and al Ma'mun for the succession which followed the death of Harun al Rashid. Its citizens seem to have favored Amin. In about 814, a certain Abu Shaikh Ganawaya who collected the expenses of the work from the "notables and rich men of the city" rebuilt the walls of Edessa. ${ }^{3}$

The misrule and disunity of the Moslem Arab Empire encouraged the Byzantines to launch vigorous offensives across the eastern frontier. From the year 927, and under the leadership of John Curcuas, their incursions met with little resistance. In a new campaign in Mesopotamia, the Byzantines besieged Edessa in the summer of 943 . Their prize was not military conquest but the portrait of Jesus (the Mandylion).

In 1030, the citadel of Edessa was handed over ${ }^{4}$ by Salman, the Turkish Envoy of Naser al Dawlah, to the Byzantine general George Maniaces, ${ }^{5}$ in return for an annual pension and a patent of

1 J.B. Segal, Edessa "The Blessed City" (Oxford University Press, 1970) 192.

2 The Chronography of Bar Hebraeus, tr. by E.A. Wallis Budge (Amsterdam: Philo Press, 1932) 96, and Tarikh Mukbtasar al Dual of Bar Hebraeus (Beirut: Catholic Press, 1958) 101.

3 The Chronicle of the Anonymous Edessan, Arabic translation by Fr. Albert Abouna (Baghdad, 1986) Vol. 2, 22.

${ }^{4}$ According to the Anonymous Edessan, 1234, Maniaces seized the citadel by force (See the Arabic translation by Albert Abouna, pp. 160-2.)

${ }^{5}$ Matthew of Edessa as quoted by Segal, Edessa "The Blessed City," $217-8$. 
nobility from the Emperor. Later, the Byzantine garrison took possession also of the city.

The following years were a chronicle of violence. The ravages of war continued. In March 1087, Edessa surrendered to the Saljuqi general Buzan, ${ }^{6}$ and in February 1098, Baldwin de Bourg took control of Edessa. Edessa had summoned the Crusaders as hired mercenaries to rescue the Eastern Christians from the Moslem Turkish yoke. ${ }^{7}$ But it quickly discovered that it had exchanged one master for another. Despite the fact that the city assumed its former prominence as a bastion of Christendom, its new rulers were foreigners who had no sympathy for the traditions and the way of life in the region. Edessa was set upon a dangerous course. ${ }^{8}$

\section{EDESSA IN THE 12 ${ }^{\text {тн }}$ CENTURY}

\section{General}

For Mesopotamia, the twelfth century was a crucial period. It was characterized by turbulent changes that encompassed political, military, ethnic structure, social and economic conditions. The period was one of turmoil, conspiracy, political assassinations, tyranny, and oppression. The Islamic Empire was in disarray. The Caliphate in Baghdad had lost its power and influence. The Turks were tightening their grip on the region. Byzantines were seizing every opportunity to regain territories lost to Moslems. Power struggle among the Turkish generals was at its highest, each of them trying to take possession of as much territory as possible. The Crusaders were battling the Turks everywhere. Constantinople was rivaling the Crusaders for hegemony over the region. As a result of this chaotic situation, the inhabitants of the region suffered heavily. Continuous atrocities, massacres, captivity, enslavement, dislodgment, evacuations and property destruction had become familiar scenes in their lives. This continuous suffering had induced corruption, fear, moral degradation, loss of hope and faith, and hardening of hearts, and had eroded mercy from souls. Poverty and epidemics were a natural outcome of such continuous afflictions.

\footnotetext{
${ }^{6}$ The Chronicle of the Anonymous Edessan, 1234, 66-7.

7 Ibid., 75-6.

${ }^{8}$ Segal, Edessa "The Blessed City," 226.
} 
Being one of the most important cities in the region, Edessa was hit the hardest.

\section{Political Situation}

[10] By the dawn of the twelfth century AD, Edessa, under Crusader rule, had become a fief of the kingdom of Jerusalem. Its ruler, Baldwin de Bouillon, had succeeded his brother Godfrey as king of Jerusalem. He, according to Matthew of Edessa, had bought the crown of Jerusalem with the "enormous sums" which he had extorted from the inhabitants of Edessa. Edessa's new ruler, Baldwin de Bourg, instated by his kinsman Baldwin de Bouillon, along with the ruler of Antioch shared the right of the king of Jerusalem to strike coins. The prince of Antioch also regarded the ruler of Edessa as his vassal; and the Byzantine Comneni emperors still continued to insist on treating both Antioch, and Edessa as subject to Constantinople by virtue of the oath of allegiance which the Franks had taken at the outset of the Crusade.

Between the Edessans and the warrior Crusaders there was now little sympathy. It seems that the code of chivalry of the Crusader nobles certainly had more in common with that of the Moslem generals than with the way of life of their native fellowChristians. There is some justification for Matthew's comment that Baldwin de Bourg "had more hatred for Christians than for the Turks."

After the defeat of Crusaders at Harran around 1102, the Turks under the leadership of Jekermish besieged Edessa. ${ }^{9}$ Tancred, ${ }^{10}$ with the help of local citizens repulsed the Turkish attack. Edessa was saved, but it had been near to falling into the hands of the enemy.

The County of Edessa was entrusted to Tancred until Baldwin who was taken prisoner at the battle of Harran was released. Tancred, however, was recalled to Antioch whose prince (Bohemund) was on a visit to Europe, and the rule of Edessa was delegated to Richard, a kinsman of Bohemund. Richard was described by the Anonymous Chronicler of Edessa (1234) as "a bad, tyrannical, unjust and greedy man. He inflicted on the Edessans cruel tortures, imprisonment, and disgrace." He collected

9 The Amir (Prince) of Mosul.

10 The Prince of Antioch and Bohemund's nephew. 
money, especially as he knew that "he was a sojourner and a passer-by, not the true lord and heir."

Edessa was again besieged, perhaps during Richard's tenure, by Jekermish in 1105 or 1106 . The Turks withdrew with a partial victory. The Western side of the church of Hagia Sophia collapsed and a great part of the building was ruined. The repeated raids of the Turkish soldiers led to scarcity of food in the city. ${ }^{11}$

[15] In 1108 both Baldwin and Joscelyn obtained their freedom. Tancred refused to hand over the County of Edessa to Baldwin. Baldwin engaged him in battle with indecisive results. He then sought the help of his former Turkish captor against Tancred, who also found allies among the Turks. Here we find the unedifying spectacle of Crusader fighting Crusader for the control of the County, each with the aid of Moslem Turks. The final outcome was a victory for Tancred. Baldwin and Tancred were reconciled, and Baldwin remained in Edessa. ${ }^{12}$

[16] In 1110, Mawdud, the governor of Mosul, threatened Edessa with a great Turkish army. Matthew of Edessa insinuates that Mawdud came at the invitation of Baldwin. Other sources allege that Tancred had summoned him. The Turks destroyed the crops and monasteries around Edessa, and a good number of Edessans were killed.

In the spring of 1112, Mawdud once again besieged Edessa, devastating the countryside. The city was in great distress. The city would have fallen to Mawdud "thanks to some Edessan traitors,"13 had it not been for Joscelyn de Courtenay's courage. Mawdud withdrew. The Franks killed and tortured innocent Edessans once again as punishment for the betrayal. Matthew of Edessa declares, "This unjust severity was odious in the eyes of the Lord."

Edessans suffered mercilessly from the Crusaders, who having crushed the aristocratic families, now turned to the populace. In 1113 Baldwin was informed by some Franks that the Edessans intended to surrender their city to the Turks. Subsequently, Baldwin expelled all the inhabitants and settled them in Samosata. He burned the houses of those who remained in Edessa in defiance

${ }^{11}$ Segal, Edessa "The Blessed City," 232.

${ }^{12}$ The Chronicle of the Anonymous Edessan, 1234, 93.

${ }^{13}$ Matthew of Edessa, as quoted by Segal, Edessa "The Blessed City," 233. The Anonymous Edessan calls them "some ten Armenians," The Chronicle of the Anonymous Edessan, 1234, 96. 
of his order. All but 24 departed (another account has 80). The 24 people had taken refuge in the Church of St. Theodore. The city was deserted.

[19] After the assassination of Mawdud of Mosul, in 1113, Edessa was once again besieged in 1114 by the Turks, led by al-Barsuqi. The gardens and crops outside the city were once again systematically destroyed, two years in a row. The Turks were not able to penetrate the defense line of the Franks.

Baldwin de Bourg left Edessa for Jerusalem without appointing a successor to himself. He left Waleran ${ }^{14}$ as his deputy. He was not to return to the County. He was made king of Jerusalem after his namesake king Baldwin of Jerusalem died in 1118.

After engaging in few battles with Turks, Waleran was removed. Baldwin appointed Joscelyn de Courtenay as his successor in the County. Ilghazi, the Artuqid ruler of Mardin, ravaged the region of Edessa in May 1120, but he did not dare to attack the city itself. The fortifications of the city were strengthened.

Toward the end of 1131, Joscelyn died of wounds received in an earlier campaign. Joscelyn's son and namesake, an Armenian on his mother's side, succeeded to the County of Edessa. Both Matthew of Edessa and the Anonymous Edessan describe him as "a foolish youth, void of understanding." The events were to prove the soundness of these historians' judgement. The desultory fighting was continued with varying outcome. But, significantly, it was now invariably in the close neighborhood of Edessa itself. The Artuqid Timurtash made frequent raids into Edessan territory, pillaging villages and farms. In 1135, a Turkish army was apparently beaten off outside the city. Three years later, in 1138, Edessa was again besieged by the Turks. A great company of Franks set out from Samosata to raise the blockade. When they had advanced a few miles they were suddenly attacked by the army of Timurtash. Most of the Franks were killed, the rest with great booty of horses and mules, were paraded in rows, bound with ropes, below the walls of Edessa. The Turks had no siege engines, and after capturing the important fort of Kisas east of Edessa they withdrew.

${ }^{14}$ Lord of Birtha. 


\section{Miscellaneous Events}

[23] In 1103 AD Edessa had a serious flood, documented by Matthew of Edessa. The flood destroyed part of the city. In November 1114, the neighboring cities were struck by a violent earthquake that caused much damage. In Edessa, 13 towers of the wall collapsed. A flood demolished the dam, attributed to Apostle Addai, in the following year. There must, nevertheless, have been a shortage of water in the city, for at this period a certain Bar Halabi ${ }^{15}$ caused a spring of water to be conveyed to Edessa. ${ }^{16}$

\section{THE DISASTER OF 1146}

[24] Before presenting an account on the disaster of 1146, it is appropriate to have a glance at the Christian communities in the Eve of this disaster.

\section{Christian Communities in the Eve of the Great Disaster of 1146}

[25] At the dawn of the $12^{\text {th }}$ century, there were four principle Christian communities in Edessa. Syrian (referred to by Western writers as Monophysities or Jacobites), Armenian, also known as Monophysites, Melkite, and Latin.

\section{The Syrians}

[26] The Syrians were the most important community in the city of Edessa and its neighborhood, thanks to their sheer number, if not for other reasons. It is no wonder, therefore, that we hear most at this period about Syrians especially since contemporary chroniclers belonged to this community.

The Syriac Orthodox community of Edessa was an indivisible part of the corrupt and unstable Edessan society as mentioned earlier. Syria and Mesopotamia were in a state of misery. The Franks and Turks were ravaging the region in its entirety, killing, robbing and brining destruction everywhere. One would not hear anything but news of turmoil, wars and fighting. As a consequence, the faith of many Syriac Christians weakened, their hearts became troubled and their thoughts were in a state of confusion. A large

15 Perhaps Barsauma Bar Shalabi.

${ }^{16}$ J.B. Chabot (ed.), The Chronicle of Michael the Syrian (Paris, 1910) 595. 
number of them had lost hope because of the severity of distresses and the continuous changes and fluctuations of political, social and ecclesiastical situations. Given this situation, it is not surprising to hear local historians complain of a decline in devoutness of Christians and in their respect and submission to their pastors. ${ }^{17}$

Following the death of Athanasius Bar Shumana, the Syriac Metropolitan of Edessa, in 1099-1100, Patriarch Athanasius, distinguished for his learning and much respected both within and outside his own church, hoped to leave the see vacant and reside at Edessa himself. The Edessan Syrians insisted, however, on exercising their prerogative of electing a Metropolitan of their own choice. They selected a monk distinguished for his eloquence and erudition, Abu Ghalib bar Sabuni of Melitine. The choice of Abu Ghalib greatly vexed the Patriarch, for he regarded him with distrust. Nevertheless he had no alternative but to accept the nomination. First, however, he imposed a condition. Volumes of the Gospel bound in silver and gold belonging to the treasury of the Patriarchate had been used as a pledge by a Syriac leader of Edessa to obtain money with which to bribe the rulers of the city. These volumes, the Patriarch insisted, were to be returned to the Patriarchate. ${ }^{18}$ Abu Ghalib assented to the condition in writing. He was consecrated in 1100-1 under the name of Basil.

Basil, under the influence of obstinate troublemakers among his congregation, refused to return the Gospels. There ensued a period of discord which was exploited by persons of ill will: on both sides the quarrel was exacerbated by unprincipled advisers. The Patriarch excommunicated Basil.

This dissension in the Syriac Church came to the notice of count Baldwin of Edessa, of Joscelyn, and even of the king of Jerusalem. Bernard, the Latin Patriarch of Antioch, intervened personally in the dispute. The details of the incidents that followed illustrate the strenuous relations between the Syrians and the Frankish authorities.

Bernard failed in his reconciliatory effort and this angered the Frankish authorities. As a result, the Syrians were in great distress.

17 The Chronicle of the Anonymous Edessan, 1234, 157.

${ }^{18}$ Detailed accounts on the status of the Syriac Orthodox community of Edessa in this period can be found in Chabot, The Chronicle of Michael the Syrian, 590-611, and in The Chronicle of the Anonymous Edessan, 1234, vol. 2, 334-8 and 342-3. 
The breach widened. The Patriarch deposed the Metropolitan and closed the churches of Edessa. For the Syrians of Edessa the situation was critical. They began to baptize their children in Latin churches. The leading priests interceded with the Patriarch, and undertook not to associate with the Metropolitan; the churches were then reopened. Metropolitan Basil was now isolated. He retired to an estate to the northwest of the city.

Upon the death of the Patriarch at the Monastery of Mar Barsauma, the Franks felt free to interfere in the ecclesiastical affairs of their Syrian subjects. Joscelyn seized the Patriarchal insignia, declaring that the election to the office of Patriarch should take place in his territory. This was done; the ceremony was held in February 1130 in the great church of the Latins, in the presence not only of the Maphrian of the East but also of Joscelyn and his officers. The new Patriarch, John, is described as dissolute, feeble in theological matters, but vigorous in anger and strife. His first act, no doubt on the advice of his Frankish masters, was to release Basil of Edessa from excommunication; but it was too late, for the letter of absolution reached the Metropolitan as he lay on his death-bed.

Power among the Syrian community now passed into the hands of "evil men"-Abdun, the chief priest and steward, and a certain Saliba, a rich priest, who was proud of his scholarly ability. When the See of Edessa became vacant, they arranged for the election of the archdeacon and steward of the church to the position of Metropolitan; he was Abdun's uncle by marriage. He received the formal name of Athanasius. His appointment was well received by the citizens, because he was a good and modest man. For five or six years he endured the intrigue and insolence of his patrons.

On the death of Patriarch Athanasius in 1143 or 1144, Basil Abu'1-Farag bar Shumana, brother of Michael bar Shumana, who had previously been Bishop of Kaishum, was transferred to the diocese of Edessa. It may have been the influence of his brother, the Administrator of Edessa that procured for Basil the appointment to the Metropolitan see.

The Syrians also had disputes with the members of other Christian sects. The incident of locust infestation in the countryside of Edessa and the use by the Edessans of the relics of St. Bar 
Sauma to dispel the swarms and their ensuing dispute with the Melkites portray rather clearly this background of sectarian strife. ${ }^{19}$

\section{The Armenians}

[36] Some of the wealthiest citizens of Edessa in this period were Armenians. Their prestige had been especially high since several rulers of Edessa and other cities in the region were Armenians. Some of these rulers were Armenian by race only, but by religion followers of the Greek Church. ${ }^{20}$ With the fall of Toros son of Hethum in 1098, and the gradual elimination by Baldwin du Bourg of the Armenian princes of the neighboring principalities, the prominence of the community, whether as a confessional or an ethnic unit, declined. The Armenians of Edessa acted as individuals rather than as a group, and they were sharply divided in their loyalties. Some had conspired to admit the Turks into the city in 1112 as we have seen; on the other hand, it was, according to one account, ${ }^{21}$ Armenians from Edessa who rescued Count Joscelyn from prison in 1123.

The Armenian Catholicus, on a visit to Edessa in 1103, was received by Baldwin du Bourg with extravagant honor and lavish gifts. On the whole, indeed, the Latin princes showed a partiality for rich Armenian chieftains. But this did not save the latter when political expediency was involved; ultimately the goodwill of the Franks brought upon the Armenian leaders, as Matthew of Edessa puts it, "terrible chastisement...on the part of the Turks and their brothers, the Byzantines."

\section{The Melkites}

The Melkites were in a difficult position in those areas under Crusader control where the political influence of Constantinople had suffered complete eclipse. The Franks insisted that the Greeks were subject to the authority of the Latin Church. At Antioch, for example, the ascendancy of the Latin Patriarch was rarely challenged by the Melkites. Nor did the Melkites fare better with

${ }^{19}$ Chabot, The Chronicle of Michael the Syrian, 615-7.

20 Philaretos, Thoros son of Hethum, Vasak of Antioch, Gabriel of Melitini, Bagrat at Tell Bashir, and his brother Kogh (thief) Basil, Constantine of Gargar.

21 The Chronicle of the Anonymous Edessan, 1234, 113-5. 
the two Orthodox groups, the Armenians and the Syrians, who were independent of the Latins; for they had not abandoned their traditional distrust and hatred of the Greek Church.

There was no Melkite bishop at Edessa. But the community, though small in number, continued in existence. Their cathedral church was the famous Church of Hagia Sophia; among their members was Abdu'l-Masih, a philosopher well known in his time. A Melkite inscription has survived in the neighborhood of Edessa; dated probably 1118-19, it is written in the Serta script employed in the regions under Byzantine rule. ${ }^{22}$

\section{The Latin Community}

[40] The cathedral church of the Latin community was the Church of St. John the Baptist in this period, where the remains of Addai (Thaddaeus) and Abgar rested in a silver coffin as we learn from an interesting description of the Church in $1145 .{ }^{23}$ Beside it stood a monastery. The Latins worshiped also in the Church of St. Stephan, in the Church of St. Thomas, probably also in the Church of the Virgin Mary. According to St. Michael the Syrian, Archbishop Benedict had a vision about the relics of Addai and Abgar. They were then discovered in the Church of St. John. The story of the vision may have been a pretext for the appropriation of this church by the Latins as their cathedral. ${ }^{24}$

[41] Under the rule of the Franks, the head of the Latin confession in Edessa had, for political reasons, influence out of all proportion to the size of his flock. He was warrior and spokesman of the citizens as well as churchman. And among the religious groups in the city he naturally assumed leadership. With matters of dogma he appears to have had little concern. But when negotiations with an enemy were to be opened it was the Latin Archbishop who took the initiative. When Baldwin was defeated by Tancred in 1108, it was evidently the Latin Archbishop who convened the citizens, and

22 The reconstructed inscription reads, "This is the grave of Constantine [in the year] 1400 and thirty. Let who [ever] reads [this, ask] pardon [for] his soul."

${ }^{23}$ By an Anonymous semi-poetic Western Syriac text written before 1109, quoted by Segal in Edessa "The Blessed City," 249.

${ }^{24}$ Segal, Edessa "The Blessed City," 237. 
in 1144 the Syrian Metropolitan Basil submitted his truce proposals to Zangi through his Latin colleague. ${ }^{25}$

\section{Events Leading to the Disaster of 1146}

[42] The Crusaders, who had managed to maintain their hold on the immediate neighborhood of Edessa, met with the Atabeg of Mosul, Imad ul-din Zangi, an exponent of skill, resourcefulness and determination at the time when the ruler of Edessa was the ineffective Jocelyn the younger. Edessa was a thorn in the side of the Moslems, and Zangi exerted every effort to neutralize it. He had earlier conveyed a message of friendship to the Franks. But later, Joceylyn drew upon himself the Atabeg's enmity by making a pact with his Artuqid rival Qara Arslan, by which time (in 1143) the two Christian kings, the Byzantine Emperor John II Comnenus, and Fulk king of Jerusalem had died.

Zangi kept watching the development at Edessa and waiting for the best opportunity to attack. When at the end of 1144 Jocelyn had left the city accompanied by a large force, Zangi sent an Army to surprise Edessa. On the 30th of November 1144, Zangi arrived to surround the city on all sides.

The events that followed are described graphically as eyewitnessed by the Syriac Metropolitan Basil bar Shumana. From his account we know that some four weeks after the siege had begun, on the 23 of December, on Christmas Eve, Zangi's troops succeeded in breaking through the walls of Edessa. Men and women, and even the monks from the hills of Edessa, fought in the two breaches from dawn. At the third hour, the Turks forced their way into the city across the bodies of the dead.

For three days Zangi gave over the city to his soldiers to ransack. On the first day about six thousand helpless Edessans were slain. Women, children and youths, who ran towards the upper Citadel in the south of the city "pressing upon each other, from fear of death and slavery, pushing upwards, treading upon one another, all were suffocated and trampled down into a solid mass," 26 for the Latin Archbishop Hugo had ordered the gate of the Citadel to be kept closed. Some five thousand people perished

25 The Chronicle of the Anonymous Edessan, 1234, 147.

${ }^{26}$ Chabot, The Chronicle of Michael the Syrian, 630-1, and The Chronicle of the Anonymous Edessan, 1234, 149. 
miserably. About ten thousand boys and girls were taken into captivity. Archbishop Hugo, on attempting to enter the Citadel, was himself cut down to pieces by an axe. ${ }^{27}$ Many priests, deacons, and monks were killed. Zangi entered the city, and, wondering at its beauty, showed magnanimity and the slaughter stopped. The lives of those in the Citadel were spared, and the city was surrendered by a certain Barsauma.

The Turks set guards the next day so that the citizens would not be at the mercy of the soldiers, and the troops were forbidden to enter. Some two thousand women and children, who were found in the upper Citadel, were carried into slavery; about ten thousand soldiers were released. The Syrians, Armenians, and Melkites were spared. The Franks were plundered of their gold and silver, their church vessels, cups and bowls, crosses and jewels. All Franks who were found were killed. Priests and notables of Edessa were stripped and sent to Aleppo. Craftsmen were set apart and put to work at their trades as prisoners. About a hundred men were tortured and slain. The remaining citizens were allowed to keep some of their possessions. Metropolitan Basil was made to swear on the Cross that he would observe loyalty to the new masters of the city.

Although the capture of Edessa was not a particularly tremendous victory as claimed by some, ${ }^{28}$ nevertheless the consequences for the Crusaders were serious. It brought to an end their pretensions to dominion east of the Euphrates. The news spread throughout Christendom that the city of Abgar had fallen to Moslems. Christian Antioch and even Jerusalem itself seemed vulnerable.

\section{EDESSA BETWEEN 1144-1146}

[48] The emotions of the Western Christians brought little consolation to the Edessans. The disaster of 1144 was commemorated by laments in Syriac by Dionysius Bar Salibi, Basil Bar Shumana and

${ }^{27}$ Gregory the Priest reports that Hugo was suffocated (quoted by Fr. Albert Abouna in The Chronicle of the Anonymous Edessan, 150.

28 Ibn al Athir exaggeratingly describes it as "a feat of arms as glorious as that of Badr." (quoted by Segal, in Edessa "The Blessed City," 247). 
others. The Catholicus Narsai IV Shnorhali wrote an elegy in Armenian on the ruined city.

The period between 1144-1146 enjoyed relative peace and prosperity. The strong Turkish rule had restored security to the city. In 1445 Zangi visited Edessa at harvest time. The account of Zangi's visit provides an interesting description of the appearance of the city at this time. ${ }^{29}$ Some of the changes brought about by the capture of Edessa by the Turks included the following:

The breaches in the wall and the seven towers were rebuilt with Arabic inscripions on them characterizing the account of the capture and the name of the ruler (Zangi). The shrine of the Confessors outside the city was razed, and its stones were used to rebuild the wall. The Turks had begun to build a castle for the ruler beside the splendid shrine of St. John in which the ruler lived. The conquerors took the shrines of Sts. Stephan and Thomas the Apostle, because, it was said, the Franks prayed in these shrines. They made the shrine of St. Thomas a stable, and that of St. Stephen a storehouse for corn and the other crops of the ruler. The shrines of St. Theodore and that of the Angel Michael on the south side of the city were pulled down and their stones were used wherever needed. The Turks also renewed and restored the mosque and the Moslem chapel which had been made the residence of the bishop of the Franks.

\section{THE DisAster of 1146}

[51] The story of Edessa does not end with the happy incident of the visit of Zangi and his acknowledged tolerance and generosity. In September 1146, Zangi was assassinated to the joy of his enemies.

Joscelyn had been humiliated by the loss of his county. Shortly after the fall of Edessa in 1144, Armenians in the city had plotted to seize it for him. The plan was discovered and the guilty men executed. With the death of Zangi, Joscelyn's hope was revived. Less than forty days after the death of Zangi, he set out with Baldwin of Mar'ash and a small troop of soldiers to surprise the city at night. The prince of Antioch refused to join. But the element of surprise had been lost. The Moslems of Aleppo heard of Joscelyn's plan and warned the Turkish garrison at Edessa. The

29 The Chronicle of the Anonymous Edessan, 1234, 158-62. 
Turks took about fifty Christian master-builders, smiths and artisans as hostages and prepared to defend the citadel.

Joscelyn's advance party reached Edessa on Sunday, September 27. They scaled the walls at night, apparently with the aid of some Armenians inside the city, ${ }^{30}$ slew the guards, and opened the gate in the south west of the walls. The Frankish cavalry and infantry entered the city. But "the brainless fools," as the chronicler ${ }^{31}$ calls them, did not engage the Turks in the citadel. On that very night they turned to plunder the shops and houses of the citizens, Moslem and Christian, good and bad, alike. The Moslems immediately retired with their families and property to the citadel. Some Moslems escaped to Harran during the night. The Crusaders spent six days in futile activity. In the meantime, the Turks were massing around the city.

A spy informed Joscelyn on the sixth day that about ten thousand Turkish soldiers were in the hills and the plain ready to join forces the next day with their compatriots inside the city. He determined to leave the same night from the North Gate. Michael the Syrian reports that Joscelyn's men set fire to the houses and goods of the Christians of Edessa before leaving the city. A great number of Edessan men, women, children, soldiers and horses caught in terror, rushed out of the city seeking protection from the Frankish forces. The Turks chased the disorganized crowd of soldiers and people who fled in panic, and slaughtered them mercilessly.

Joscelyn escaped with a few followers to Samosat. Baldwin was slain along with many soldiers. Thirty thousand people were killed. Sixteen thousand women, youths and children were taken into slavery, stripped of their clothes, barefoot, their hands bound, forced to run beside their captors on horses. Those who could not endure were pierced by lances or arrows, or abandoned to wild animals and birds of prey. Priests were killed out of hand or captured; only few escaped. The Archbishop of the Armenians was sold in Aleppo. Basil bar Shumana narrowly made his escape to Samosata.

The whole city of Edessa was given over to looting. At the first destruction in 1144, the pillage lasted two days only, and the city

${ }^{30}$ Chabot, The Chronicle of Michael the Syrian, 634.

31 The Chronicle of the Anonymous Edessan, 1234, 166. 
was hurriedly saved and the destruction restrained at the command of Zangi. In this destruction of 1146, ruin was complete. The Turks went about the city looting and destroying not for days, but for a whole year. ${ }^{32}$

Living only about $100 \mathrm{~km}$ North in the Monastery of Mar Barsauma near Melitene, Patriarch Michael, then a monk at the age of 20, must have heard and read detailed eyewitness accounts, including that of Metropolitan Basil Bar Shumana, of the disaster of 1146 and the previous one in 1144. In his Chronicle he gives detailed accounts on the painful events that took place during his lifetime in Edessa.

\section{THe Christian COMMUNiTy AFTER THE DISASTER OF 1146}

[58] The Christian community of Edessa never recovered after the disaster of 1146. During and after the disaster, they felt they had been abandoned. The Anonymous Syrian Edessan Chronicler wrote: "The Christians who lived in the Western regions (of Mesopotamia) had no mercy in their hearts, but cruelty, callousness, hardness of heart and wickedness of thought, especially among the priests, monks, and bishops. Christians east of the Euphrates used their limited resources to ransom the Edessans who had been carried into captivity. John, Bishop of Mardin, an Edessan in origin, is singled out for an especial praise.

The tragedy of Edessa was commemorated in sermons and elegies as mentioned earlier. "After the passage of few years," writes Segal, "the story of the city of Abgar, whose traditions were woven into the fabric of Christian history, had become no more than a subject for academic argument on the workings of Providence." 33

[60] After the disaster of 1146, Christian community suffered a swift moral decline. Corruption became widespread. Christian population became an insignificant minority and virtually disappeared from view. Less than thirty years after the disaster of 1146, they tried to stage a half-hearted demonstration "like the old practices." "The church bells rang, the populace were sworn by the Cross and the Gospels, meetings were called for, and delegates

32 The Chronicle of the Anonymous Edessan, 1234, 172.

33 Segal, Edessa "The Blessed City," 254. 
were dispatched. The governor, however, thwarted the movement by a contemptuous use of bribes and banished its instigators. The only result, comments the Chronicler sadly, "was that the Christians became unpopular, ... and won a bad name." 34

Christian shrines which had long been a memorial of Roman and Byzantine Edessa were now empty and deserted. We have seen how the famous churches of St. Thomas and St. Stephen were put to menial use as a stable and granary. Other churches were dismantled and their stones were used to build the citadel and the walls. The church of Hagia Sophia, once counted as one of the wonders of the world, had deteriorated and was demolished and its fabric transferred to the citadel and to the mosque of Harran. The beautiful church of St. John the Baptist had been employed as a storehouse for wool. In 1183 a lighted lamp set fire to the inflammable material, and the whole building perished in a molten blaze. Meanwhile the Moslem population of Edessa grew and so too did the number of its mosques side by side with the public baths, khans and markets.

Edessa could no longer survive as a Christian city alone in a cohesive Moslem empire. On the death of Zangi's son it passed to his generals. Later it became the property of Saladin and his Ayyubid successors. A flash of the old spirit of independence flared up in 1234 when its inhabitants resisted the troops of Mosul. The soldiers breached the walls, sacked the town and deported its inhabitants to the west.

[63] Edessa shared passively the fate of its neighbors. It experienced the visitation of the Tatars in 1244 and surrendered to Hulagu in 1260. In 1637 it was incorporated in the Ottoman Empire by the campaign of Murad IV.

A census published in 1908 by Ottoman authorities puts the population of Edessa and surroundings (the County of Edessa consisting of Edessa, Birejik, Qal'at Rrum and Harran) in the vicinity of 72,000 . Only $19 \%$ were Christians. As a result of the 1914 massacres of Armenians and Syrians in Turkey, the Christian population of Edessa greatly diminished. On the eve of their forced mass exodus in 1924, the Syriac Orthodox population of Edessa was approximately 2,500. Today no Christian soul exists in Edessa.

34 The Chronicle of the Anonymous Edessan, 1234, 221-2. 


\section{REFERENCES CITED}

The Chronicle of Michael the Syrian. Published by J. B. Chabot. Paris, 1910.

The Chronography of Bar Hebraeus. Translated by E. A. Wallis Budge. Amsterdam, 1932.

Gregorius Ibn al Ibri (Bar Hebraeus) Tarikh Mukhtasar al duwal. London, repr. 1976.

Gregorius Bar Ebroyo, Makhthbonuth Zabne, in Eastern Syriac. Leipzig, 1890.

Tarikh al Rahawi al Majhul, (2) "The Chronicle of the Anonymous Edessan," vol. 2, 1234. Arabic Translation by Fr. Albert Abouna. Baghdad, 1986.

Abouna, A., and J. M. Fiey. Anonymi auctoris Chronicom ad annum Christi 1234 Pertinens, II. CSCO, 2, Scr. Syri, 154; 1974.

Segal J. B., Edessa “The Blessed City.” Oxford University Press, 1970.

\section{SELECT BIBLIOGRAPHY}

Baldwin, M.W. The First Hundred Years (K. M. Setton, A History of the Crusades). 1955.

Bar Hebraeus, Gregory abu l-Farag: J.B. Abbeloos and T.J. Lamy, Gregorii Barhebraei Chronicon Ecclesiasticum. 1872-7.

Bayer, T.S. Historia Osrhoene et Edessena, ex numis illustrata. 1734.

Chabot, J.B. Edesse pendant la premiere croisade' CRAI. 1918, 431.

- Incerti auctoris Chronicon Pseudo-Dionysianum vulgo dictum. CSCO, 91, 104, Scr. Syri, 43, 53; 1952-3.

- Anonymi auctoris Chronicon ad annum Christi 1234 Pertinens. CSCO, 81-2, Scr. syri 36-7; 1953.

Dowesett, C.J. “A Twelfth-century Armenian Inscription at Edessa," in In Memoriam Vladimir Minorsky. 1970.

Duval, R. Histoire Politique, religieuse et litteraire d'Edesse jusque a la premiere croisade. 1892.

Ibn al-Athir, 'Izz al-din abu 1-Hasan 'Ali Muhammad, Al-Kamil Fi l-ta'rikh, ed. C.J. Tornberg. 1867-76.

Le Strange, G. The Lands of the Eastern Caliphate. 1930.

Matthew of Edessa: J.P.L.F.E. Dulaurier. Chronique de Matthieu d'Edesse (962-1136) avec la continuation de Gregoire le Pretre jusqu'en 1162. 1858.

Ostrogorski, G. History of the Byzantine State. 1956.

Parry, O.H. Six Months in a Syrian Monastery. 1895.

Runciman, J.C.S. "Some Remarks on the Image of Edessa," Cambridge Historical Journal III (1929-31): 238.

- A History of the Crusades. 1965.

Segal, J.B. "New Syriac Inscriptions from Edessa," BSOAS XXII (1959): 23. 
Segal, J. B. Edessa and Harran. An Inaugural Lecture. 1963.

Thomson, R.W. "An Eighth-century Melkite Colophon from Edessa," JTS N.S. XIII (1962): 249.

Tritton, A.S., and H.A.R. Gibb. "The First and Second Crusades from an Anonymous Syriac Chronicle," JRAS (1933): 69, 273. 
